\title{
MANAGEMENT ANALYSIS OF MUNICIPAL PROPERTY CASTLES: FORTIFICATIONS IN THE PROVINCE OF ALICANTE (VALENCIAN COMMUNITY)
}

\author{
J.A. MIRA RICO \\ ICOFORT-ICOMOS, Castalla Municipal Service for Cultural Heritage, Spain.
}

\begin{abstract}
Valencian castles have been studied from very different approaches to a greater or lesser degree. This way, it has been possible to better understand their history and morphology, the materials used in their construction, their pathologies, as well as other aspects related to people who occupied them at different times in history. Furthermore, multiple interventions have been carried out in order to improve their condition and restore them for cultural, social and tourist uses. Nevertheless, the lack of analysis focused on how fortifications are managed should be noted. In order to tackle this situation, an unpublished doctoral thesis project is being developed within the Department of Prehistory at the University of Alicante since 2013. This project has a specific line of research focusing on cultural heritage management, especially on how castles are managed in the province of Alicante. To do this, a qualitative research methodology and a specific method of semi-structured interviews to specialists mostly municipal technicians: architects, cultural heritage experts and archaeologists, among others - are employed. The interview consists of 59 questions grouped in six blocks: interviewed people data, general management data, management data - research, management data - preservation, management data - restoration and management data - didactics and dissemination. This project will make known the preliminary results from the research applied in 43 fortifications, owned by several municipalities of the province of Alicante. To better facilitate their study, these castles have been distributed into seven groups depending on the number of inhabitants of the municipalities where they are located, from smaller to greater number of residents.

Keywords: castles, cultural heritage management, municipalities, province of Alicante, qualitative methodology.
\end{abstract}

\section{INTRODUCTION}

Valencian castles - mostly of public and especially municipal property - have been studied from very different approaches due to the great interest they have aroused in society. Thus, it has been possible to know their history and morphology, the materials used in their construction, their pathologies, as well as other aspects related to people who have occupied them at different times in history. Likewise, many actions of preservation and restoration have been performed to improve their conditions and restore them for uses according to current needs. The use of didactics and dissemination made to transform them into cultural and tourist centres are especially worth stressing. This is the case of some fortifications included in this project, such as Castalla Castle or Biar Castle [1, 2].

\section{WHY AN INVESTIGATION OF THESE CHARACTERISTICS?}

Despite the interest that castles arouse, as well as actions carried on them and published works, the management of fortifications in the Valencian Community, and specifically in the province of Alicante, has not yet been analysed. Therefore, this project is justified by the need for a study on how municipalities have managed their castles between 2003 and 2013 in order

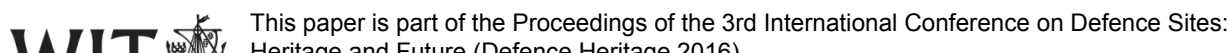
Heritage and Future (Defence Heritage 2016)

CONFERENCES www.witconferences.com
} 
to fill the void in this area: knowing their similarities, differences, strengths and weaknesses as well as proposing measures to help them to begin, improve and/or promote their current management policies. In this regard, a doctoral thesis is being developed since 2013 within the Department of Prehistory at the University of Alicante. In fact, two previews of this doctoral thesis have already been published [3].

On the basis of above, this project aims to achieve the following two purposes:

- General purpose: Knowing how municipalities in the province of Alicante have managed their fortifications between 2003 and 2013.

- Specific purposes: Knowing who - technical managers in cultural heritage, tourism, museum directors, etc. - and which areas and/or municipal institutions - cultural heritage services, cultural services, museums, tourist offices, etc. - are responsible for this management; identifying their similarities and differences; and knowing what research, preservation, restoration, didactics and/or dissemination have been carried out.

From the above-stated purposes, four research questions have been put forth [4]: How have municipalities in the province of Alicante managed their castles? Who has managed them? Which areas or institutions are in charge of their management? Is there a single model of management? These questions are reflected in the following working hypothesis: the size of these municipalities, managers' training and municipal areas and/or institutions in charge have conditioned the management of castles of municipal property located in the province of Alicante between 2003 and 2013.

\section{METHODOLOGY}

In order to comply with these purposes, as well as validate and refute the hypothesis, the methodology of qualitative research has been employed [4], specifically semi-structured interviews to local experts. This model has been chosen because it allows to focus the interview not on the person, but on his/her quality of specialist and collect information about the subject of study. In this way, 'the expert is integrated into the study, not as an individual case, but as a representation of a group (of experts) (...)', a fact that allows to analyse and compare '(...) the contents of expert's knowledge' [4]. This knowledge becomes very interesting for the study, because interviewed people are responsible for the management in these fortifications. The case of Sax is an exception: the interviewed person is an expert who does not work in the city council and does not manage the fortification directly, but he drafted its master plan. In the case of Castalla, the interviewed person is the same who has carried out this project because there is only a technical manager. That is, he is both a doctoral candidate and an expert. From a methodological point of view, being the object and subject of a study at the same time is strange, but this is because there are no more technical managers to interview at the Castalla Municipal Service for Cultural Heritage. Castalla Castle could have been left out of this research, but it has been considered for its historical significance, as well as for the work that is being done on it. Finally, it must be noted that questions have been answered honestly, and all the responses can be contrasted irrefutably with some projects, information available in other documents, websites and press.

On the other hand, like structured interviews and in-depth interviews, semi-structured interviews also present advantages and disadvantages [5], which we have tried to avoid during the study period between June 2013 and December 2014.

The interview consists of 59 questions grouped into six blocks: interviewed people data, general management data, management data - research, management data - preservation, management data - restoration, and management data - didactics and dissemination. 


\subsection{Selection criteria of the sample}

The sample was limited to achieve a feasible study taking into account those fortifications considered in the General Inventory of Valencian Cultural Heritage, while other interesting and architectural elements have been left out because they are considered as other kinds of architecture, as well as those fortifications masked by later works such as Benidorm Castle (Benidorm). The establishment of a geographical framework (province of Alicante, Fig. 1) a privileged place for its history as a part of al-Andalus and the crowns of Aragon and Castille, with 56 public and private fortifications - and public property castles gain importance because the purpose of this project is to know how municipalities manage them. However, private fortifications have been left out.

Although in principle 47 castles were selected, only 43 have been studied because four experts declined to participate in this research. The final sample was grouped into similar environments because it made no sense to compare the management carried out in a middlesized municipality as Castalla with Alicante, the capital of the province: their resources are not logically the same. The criteria followed to establish their environments have been the population for municipalities with a similar size, which must have the same resources to manage despite the often varying ground reality. So, taking advantage of the distribution made by the National Statistics Institute of Spain, which classifies the size of municipalities according to their population, these were divided into seven groups to classify each castle (Table 1).

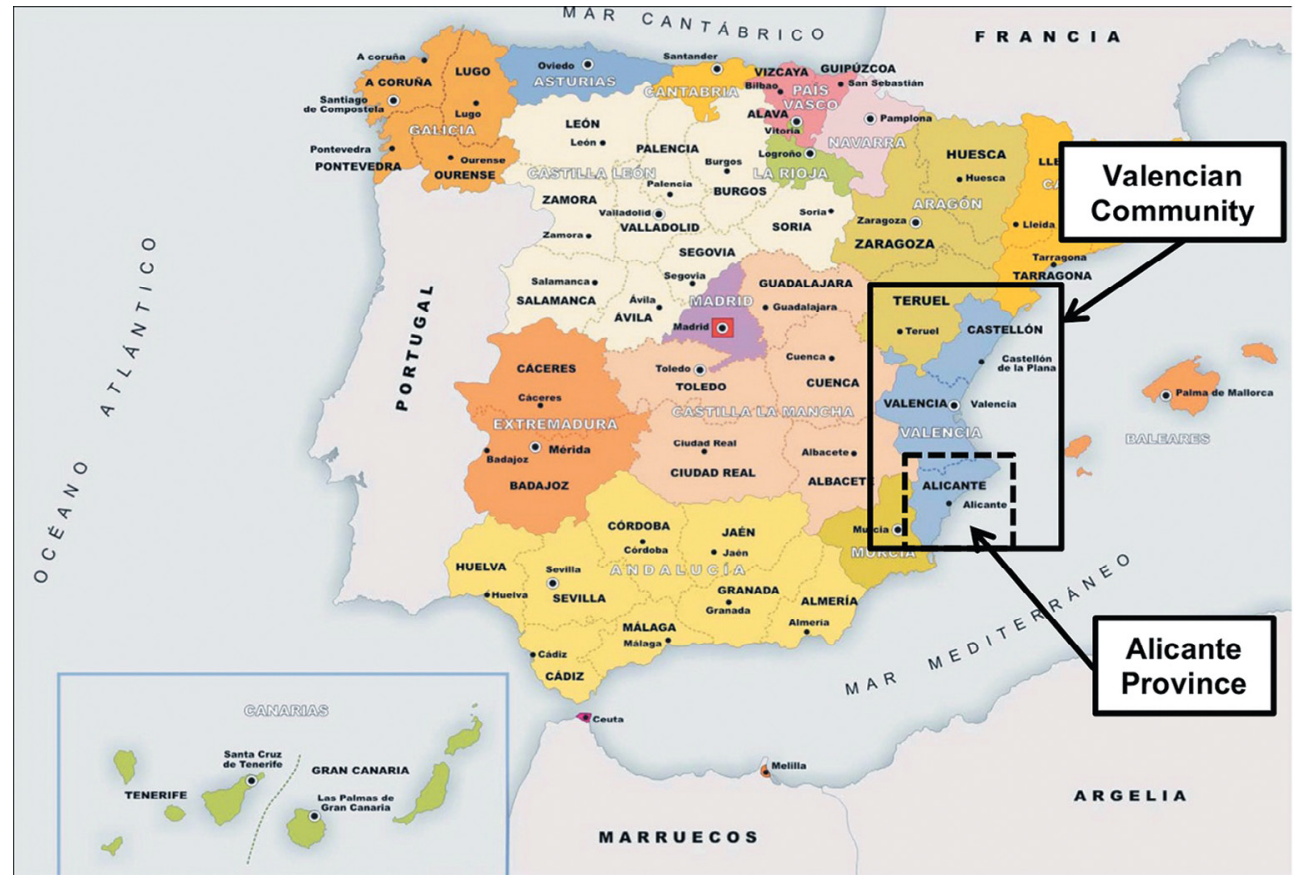

Figure 1: Location of the Valencian Community and the province of Alicante in the Iberian Peninsula (prepared by the author from http://www.mecd.gob.es/portugal/dms/ consejerias-exteriores/portugal/publicaciones/MAPAPOLITICO.pdf). 
Table 1: Groups, municipalities and profiles of interviewed people.

\begin{tabular}{|c|c|c|c|}
\hline $\begin{array}{l}\text { Number of } \\
\text { group }\end{array}$ & Municipalities & Castles & $\begin{array}{l}\text { Professional profile } \\
\text { of interviewed people/ } \\
\text { area(s) of management }\end{array}$ \\
\hline \multirow{14}{*}{$\begin{array}{l}1(101-1,000 \text { citi- } \\
\text { zens) }\end{array}$} & Balones & $\begin{array}{l}\text { Costurera or Seta } \\
\text { Castle }\end{array}$ & $\begin{array}{l}\text { Architecture-urbanism/ } \\
\text { unknown }\end{array}$ \\
\hline & Benifallim & Benifallim Castle & $\begin{array}{l}\text { Architecture-urbanism/ } \\
\text { unknown }\end{array}$ \\
\hline & Bolulla & Garx Castle & $\begin{array}{l}\text { Architecture-urbanism/ } \\
\text { urbanism }\end{array}$ \\
\hline & Castell de Castells & $\begin{array}{l}\text { Castell de Castells } \\
\text { Castle }\end{array}$ & $\begin{array}{l}\text { Architecture-urbanism/ } \\
\text { culture }\end{array}$ \\
\hline & Confrides & Alfofra Castle & $\begin{array}{l}\text { Architecture-urbanism/ } \\
\text { unknown }\end{array}$ \\
\hline & $\begin{array}{l}\text { El Camp de } \\
\text { Mirra }\end{array}$ & Almizra Castle & $\begin{array}{l}\text { Architecture-urbanism/ } \\
\text { culture }\end{array}$ \\
\hline & $\begin{array}{l}\text { El Castell de } \\
\text { Guadalest }\end{array}$ & Guadalest Castle & $\begin{array}{l}\text { Architecture-urbanism and } \\
\text { tourism/culture and tourism }\end{array}$ \\
\hline & $\begin{array}{l}\text { La Vall de Gal- } \\
\text { linera }\end{array}$ & $\begin{array}{l}\text { Alcalà or Benissili } \\
\text { Castle }\end{array}$ & $\begin{array}{l}\text { Architecture-urbanism/ } \\
\text { unknown }\end{array}$ \\
\hline & La Vall de Laguar & Laguar Castle & $\begin{array}{l}\text { Architecture-urbanism/ } \\
\text { unknown }\end{array}$ \\
\hline & Millena & Travadell Castle & $\begin{array}{l}\text { Architecture-urbanism/ } \\
\text { unknown }\end{array}$ \\
\hline & Penàguila & Penàguila Castle & $\begin{array}{l}\text { Architecture-urbanism/ } \\
\text { unknown }\end{array}$ \\
\hline & Planes & $\begin{array}{l}\text { Planes Castle } \\
\text { Margarida Castle }\end{array}$ & $\begin{array}{l}\text { Architecture-urbanism/ } \\
\text { culture and urbanism }\end{array}$ \\
\hline & Sella & $\begin{array}{l}\text { Santa Bàrbara } \\
\text { Castle }\end{array}$ & $\begin{array}{l}\text { Architecture-urbanism/ } \\
\text { culture }\end{array}$ \\
\hline & Tàrbena & Tàrbena Castle & $\begin{array}{l}\text { Architecture-urbanism/ } \\
\text { culture }\end{array}$ \\
\hline \multirow{6}{*}{$\begin{array}{l}2(1,001-5,000 \\
\text { citizens })\end{array}$} & Agost & $\begin{array}{l}\text { Agost Castle } \\
\text { Murta Castle }\end{array}$ & Culture/culture \\
\hline & Biar & Biar Castle & $\begin{array}{l}\text { Architecture-urbanism and } \\
\text { tourism/culture, tourism } \\
\text { and urbanism }\end{array}$ \\
\hline & Busot & Busot Castle & $\begin{array}{l}\text { Architecture-urbanism/ } \\
\text { heritage }\end{array}$ \\
\hline & $\begin{array}{l}\text { Polop de la } \\
\text { Marina }\end{array}$ & $\begin{array}{l}\text { Polop de la Marina } \\
\text { Castle }\end{array}$ & $\begin{array}{l}\text { Architecture-urbanism/ } \\
\text { culture }\end{array}$ \\
\hline & Relleu & Relleu Castle & Culture/culture \\
\hline & Tibi & Tibi Castle & $\begin{array}{l}\text { Architecture-urbanism/cul- } \\
\text { ture, heritage and urbanism }\end{array}$ \\
\hline
\end{tabular}




\begin{tabular}{|c|c|c|c|}
\hline \multirow{5}{*}{$\begin{array}{l}3(5,001- \\
10,000 \text { citizens })\end{array}$} & Banyeres de & Banyeres de & $\begin{array}{l}\text { Culture/culture, festivities, } \\
\text { heritage and tourism }\end{array}$ \\
\hline & $\operatorname{Cox}$ & Santa Bàrbara & Architecture-urbanism/ \\
\hline & & Castle & urbanism \\
\hline & Pedreguer & Ocaive Castle & $\begin{array}{l}\text { Architecture-urbanism/ } \\
\text { public works and urbanism }\end{array}$ \\
\hline & Xixona & Torre Grossa Castle & Culture/cultural heritage \\
\hline \multirow{9}{*}{$\begin{array}{l}4(10,001- \\
20,000 \text { citizens })\end{array}$} & Callosa de & Callosa de Segura & Culture/culture \\
\hline & Segura & Castle & \\
\hline & Castalla & Castalla Castle & Culture/cultural heritage \\
\hline & Cocentaina & $\begin{array}{l}\text { Cocentaina Castle } \\
\text { Penella Castle }\end{array}$ & Culture/culture \\
\hline & Guardamar del & Guardamar del & Culture/archaeological \\
\hline & Segura & Segura Castle & heritage \\
\hline & Monòver & Monòver Castle & $\begin{array}{l}\text { Architecture-urbanism/ } \\
\text { unknown }\end{array}$ \\
\hline & Pego & Ambra Castle & $\begin{array}{l}\text { Architecture-urbanism/ } \\
\text { Culture }\end{array}$ \\
\hline & Sax & Sax Castle & $\begin{array}{l}\text { Culture, academy, } \\
\text { architecture-urbanism and } \\
\text { environmental/culture }\end{array}$ \\
\hline \multirow{3}{*}{$\begin{array}{l}5(20,001- \\
30,000 \text { citizens })\end{array}$} & Aspe & $\begin{array}{l}\text { Aljau Castle } \\
\text { Rio Castle }\end{array}$ & Culture/culture \\
\hline & Ibi & Vermell Castle & $\begin{array}{l}\text { Architecture-urbanism/ } \\
\text { urbanism }\end{array}$ \\
\hline & Novelda & Mola Castle & Culture and tourism/culture \\
\hline \multirow{3}{*}{$\begin{array}{l}6(30,001- \\
50,000 \text { citizens })\end{array}$} & Dénia & Dénia Castle & Culture/culture \\
\hline & Petrer & Petrer Castle & Culture/culture and heritage \\
\hline & Villena & $\begin{array}{l}\text { Atalaya Castle } \\
\text { Salvatierra Castle }\end{array}$ & Culture/culture \\
\hline $\begin{array}{l}7(50,001- \\
100,000 \\
\text { citizens })\end{array}$ & Elda & Elda Castle & Culture/culture and heritage \\
\hline
\end{tabular}

\subsection{Selection criteria of interviewed people}

After collecting and distributing the castles in their respective groups, the next step was to determine who should be interviewed. The requirements were to have a technical profile and develop their work in those city councils responsible for the fortifications - whether they are public officials or ordinary people. In this sense, the most suitable figure to be interviewed is the technical manager in cultural heritage, but many city councils do not have the concerned technical manager. Therefore, in most cases, other experts have been interviewed (Table 1). 


\subsection{Time framework}

The choice of the time framework - 2003-2013 - is related to a question of functionality since for a successful outcome of a research with a large sample - in some cases managed for a long time - it is necessary to have chronological limits. In addition, they have the advantage of being able to compare the management before (2003-2007) and during (2008-2013) the crisis.

\section{CONCEPTUAL AND THEORETICAL FRAMEWORK}

The conceptual and theoretical framework that supports this thesis is not strictly a theoretical framework to use. This is because the theoretical production related to cultural heritage management at municipal level is little, and null in some cases. Keeping this fact in mind, this conceptual and theoretical framework has been structured following these issues - which are not developed for reasons of space:

- The definition of cultural heritage, understood as a multifaceted term that can be analysed from international and national regulations, as well as from the academic and scientific world and the society.

- The explanation of cultural heritage management from academic, scientific and professional levels.

- The diversity in managing cultural heritage with reference to the Mediterranean context Spain within its 17 autonomous communities, and the autonomous cities of Ceuta and Melilla - and the Anglo-Saxon context -United Kingdom of Great Britain and Northern Ireland within the nations of Scotland and England.

- The identification of classic and new approaches in the analysis of castles from references in bibliographic portals.

- The study of national experiences and specific cases - National Plan of Defensive Architecture - and those international - ICOFORT, Scottish Castle Initiative, Dover Castle (Dover, England) and Castle Hill National Historic Site of Canada (Placentia, Canada) within the Mediterranean and Anglo-Saxon contexts.

\section{CHARACTERISTICS OF THE SAMPLE}

The entire project contains a file with many interesting data about castles - their chronological and cultural secondment, if they can be visited or not, among other aspects - that have not been included for obvious reasons. However, this section has a few general references to learn more about these fortifications [6-9].

\section{ANALYSIS OF EXPERTS' INTERVIEWS AND CONCLUSIONS}

Firstly, this project and the doctoral thesis of which it is a part (unprecedented from an academic point of view) have allowed us to know and learn the management that municipalities of the province of Alicante have carried out between 2003 and 2013. This is a project that complements the traditional historical research - archaeological, architectural and documental - with regard to fortifications.

Furthermore, the analysis of the answers provided by experts has served, in general, to obtain an overview of each raised issue, complete with the purposes, and verify or rule out the hypothesis formulated.

Additionally, this study has achieved the general purpose of knowing how municipalities in the province of Alicante have managed their fortifications between 2003 and 2013. 
Specifically, of 43 studied castles - divided into seven groups according to the municipalities where they are located - 12 (27.91\%) have not been managed, $19(44.18 \%)$ have been managed punctually - at least one action has been made - and $12(27.91 \%)$ have been managed continuously - actions have been made from time to time. So, within the same context, unmanaged castles have been documented according to time framework. It may be that fortifications were managed previously or later on, along with others that have been managed punctually and/or continuously. In conclusion, specific purposes have been achieved:

- It has been determined who - technical managers in cultural heritage, tourism, museum directors, etc. - and which areas and/or municipal institutions - cultural heritage services, cultural services, museums, tourist offices, etc. - are responsible for this management. As seen in Table 1, the profile related to architecture-urbanism predominates, although many fortifications depend on the area of culture. Nevertheless, in other cases the area which they belong to cannot be identified.

- Similarities and differences, at the management level, have been identified among the studied fortifications. In this sense, one of the main differences is the absence of a single management model. As seen in group 4 [3], each fortification is different: there are managed fortifications, others managed punctually and also unmanaged. On the other hand, one of the similarities is the absence of management tools except in Castalla Castle (group 4), Dénia Castle (group 6) and Elda Castle (group 7). This is an anomalous situation, especially if it is compared with the management in England or Scotland, or Canada, where each fortification has its own management plan.

- Research, preservation, restoration, didactics and dissemination developed in these castles have been known. But not all of them have equal impact because they have been direct on castles - or indirect. These actions are more numerous and regular in fortifications of groups 4, 5, 6 and 7 than in fortifications of groups 1,2 and 3. The castles with the greatest number of actions are Castalla Castle and Sax Castle in group 4, Atalaya Castle and Dénia Castle in group 6 and Elda Castle in group 7. Moreover, there are still a few unmanaged fortifications (31 vs 12).

Finally, the hypothesis raised in point 2 has been validated. The size of municipalities is an important factor when managing - and not managing - continuously and punctually these fortifications. In groups 1, 2 and 3 it is common to see unmanaged castles and castles managed punctually. In groups 4, 5, 6 and 7 fortifications managed continuously predominate except Vermell Castle in group 5. Another factor that has affected the management is managers' training. As can be seen, manager's profiles are cultural from group 3 to group 7. So, there are a lot of fortifications managed continuously or punctually with a large number of actions and only a few have not been managed - for example, Ocaive Castle in group 3 and Vermell Castle in group 5. It is true that professional profiles related to culture have been little in groups 1 and 2, but many castles have been managed punctually. Nevertheless, this management has had very few actions. On the other hand, the municipal areas of management are another factor to consider in this case. As it can be seen, a lot of castles depend on culture and cultural heritage in groups 4, 5, 6 and 7: Monòver Castle (group 4), where the interviewed person could not specify the area although some actions have been developed; and Vermell Castle (group 5), which depends on urbanism but any action has been carried out. However, fortifications of groups 1, 2 and 3 have a varied situation. For example, most of the castles in group 1, whose areas have not been determined, are unmanaged - except 
Tàrbena Castle that depends on culture. The rest are managed punctually and there are no fortifications managed continuously, as well as castles not belonging to any area in group 2 .

Lastly, this research shows how management is focused on castles in the context of the study - province of Alicante. This pattern contrasts with Scotland and England, or Canada, where the administration covers not only fortifications but also the rest of cultural heritage tangible and intangible - and natural heritage located in castles. The management of Castalla Castle heritage site is an exception in the province of Alicante, which consists of Castalla Castle and Sax Castle [10].

\section{REFERENCES}

[1] Menéndez Fueyo, J.L., Bevià i Garcia, M., Mira Rico, J.A. \& Ortega Pérez, J.R. (eds.). El Castell de Castalla. Arqueología, arquitectura e historia de una fortificación medieval de frontera. MARQ: Alicante, p. 309, 2010.

[2] Del Rey, M. \& Gallud, A., Intervención y consolidación del segundo recinto amurallado del Castillo de Biar. Arché (4-5), pp. 427-438, 2009.

[3] Mira Rico, J.A., La gestión municipal de los castillos valencianos. Análisis de los casos de Callosa de Segura, Castalla, Cocentaina, Guardamar del Segura, Monòver, Pego y Sax (provincia de Alicante). Proceedings of the International Conference on Modern Age Fortifications of the Western Mediterranean Coast Defensive Architecture of the Mediterranean XV to XVIII Centuries, ed. P. Rodríguez-Navarro, Universitat Politècnica de València: València, 2015. Available at http://ocs.editorial.upv.es/index.php/ FORTMED/FORTMED2015/paper/view/1749 (accessed 10 December 2015).

[4] Flick U., Introducción a la investigación cualitativa, Ediciones Morata: Madrid, p. 324, 2004.

[5] Pérez Santos, E., Estudio de visitantes en museos: metodología y aplicaciones, Ediciones Trea: Gijón, p. 256, 2000.

[6] Azuar Ruiz, R., Castellología medieval alicantina: área meridional, Diputación de Alicante: Alicante, p. 250, 1981.

[7] Azuar Ruiz, R. \& Navarro Suárez, F.J., Castillos de Alicante, Ediciones Lancia: León, p. 96, 1995.

[8] Ferrer Marset, P. \& Català Ferrer, E., El Comtat: una terra de castells, Centre d'Estudis Contestans: Cocentaina, p. 122, 1996.

[9] Segura Herrero, G. \& Simón García, J.L., (eds.) Castillos y torres en el Vinalopó. Centre d'Estudis Locals del Vinalopó: Petrer, p. 236, 2001.

[10] Mira Rico, J.A., Bevià i Garcia, M. \& Ortega Pérez, J.R., Del Castell de Castalla al Conjunt Patrimonial del Castell de Castalla: un nuevo enfoque en la gestión del patrimonio cultural valenciano. Proceedings of the International Conference on Modern Age Fortifications of the Western Mediterranean Coast Defensive Architecture of the Mediterranean XV to XVIII Centuries, ed. P. Rodríguez-Navarro, Universitat Politècnica de València: València, 2015. Available at http://ocs.editorial.upv.es/index.php/ FORTMED/FORTMED2015/paper/view/1748 (accessed 11 December 2015). 